UDC 342.92

DOI https://doi.org/10.32849/2663-5313/2020.3.23

Vladyslav Yefimenko,

Student of the II course of master degree

of Law Faculty

of Taras Shevchenko National University of Kyiv

\title{
THE PRINCIPLE OF SUBSIDIARITY IN MODERN LEGAL SYSTEMS
}

The article is devoted to the coverage of the question of the role and the importance of the principle of subsidiarity as one of the principles that helps to regulate the relationships between different levels of authorities, institutions, associations. With the long history, the principle becomes nowadays actual for the development of the public regulation sphere of different legal systems of democratic States and regional international organizations. The principle of subsidiarity is an inseparable part of the legal systems of the European Convention on Human Rights and of the European Union legal order, but as having the "broad" and "narrow" sense, the approaches to the principle may differ. In addition, the article raises the question of the processes that influenced the historical development of the principle of subsidiarity, as it not exclusively the legal principle and can be seen in other spheres, such as religious doctrine of the catholic church, which has ethical principles at its basement. Nevertheless, paying attention to the role of the principle in modern legal systems, the question of the importance of the principle for the actual future of Ukraine is also researched, as the principle can take part in the basic group of principles that should regulate the administrative reforms and the relationships of institutions. The publication searches for the connection of the principle of subsidiarity to the other principles of administrative law and classifications of the principles, that may help identify the position of the principle of subsidiarity within the system of modern administrative law. The article pays attention to the approach not only of the scholars to the principle of subsidiarity, but also of the judge, from the point of the machinery of the principle within the legal system of European Convention on Human Rights, as one of the types of specific sense of the principle. In the end, the article underlines the importance of the notice and respect to the principle of subsidiarity according to the tendencies of modern democratic states and the future of the development of constitutional states, providing respect to their citizens.

Key words: administrative law principle, public regulation, public authorities, European Union, European Convention on Human Rights.

Formulation of the problem. The principle of subsidiarity is a legal principle that is getting more and more actuality nowadays. It is actively used by the European Court of Human Rights (hereinafter - Strasbourg Court, or ECtHR), by the institutions of the European Union, it has several approaches within the legal doctrine, within the canonic doctrine of Catholic Church. Nevertheless, the understanding of the principle within some of the legal systems is unstable and needs more concretization as the principle has very positive aspects for the purposes of the positive development of the modern democratic States. The principle have taken place in the administrative reform of Ukraine or being implemented in the legal acts within the Ukrainian legal order, taking positive aspects of the principle and to be in line with the euro integration and decentralization processes that could ease the work of the public authorities, providing more freedom and respect to the local levels of administration.

Analysis of recent research. The question of the role of the principle of subsidiarity was researched by Alla Pukhtetska, Ihor Hrytsiak among the Ukrainian scholars. Ihor Hrytsiak has researched the European Union legal order, the supranational EU institutions and the Member States institutions, the legal regulation of the European Union, including the principles that at the basement of the Union's system define the roles, the directions, the powers of the institutions at national and supranational level, including the principle of subsidiarity. Alla Pukhtetska researched the European principles of administrative law, the classifications and the approaches of different scholars to the European principles of administrative law, paying attention to the subsidiarity too. The judges, such as Sabino Cassese, Danute Jociene, present their own positions on the principle of subsidiarity within the system of the European Convention on Human Rights, which has seriously developed and interpreted after the High Level Conferences on the Future of the European Court of Human Rights. Other scholars all over the world have paid their attention to the principle of subsidiarity, 
such as Alastair Mowbray, Samantha Besson etc. However, the approaches of the scholars still differ and the importance of the principle of subsidiarity for the future of the legal system of Ukraine are not highly raised.

Objectives of research. The main objective of the article is to research the main approaches of the scholars to the principle of subsidiarity as the legal principle of administrative law and which approaches are used in the legal systems of the European States. Making conclusions from the research, to present thoughts on which approach and which features of the principle of subsidiarity would positively affect the development of Ukraine as the modern European State.

Presenting main material. The principle of subsidiarity has an old historical background, which starts from the Ancient Rome during the expansion of the surrounding the Empire lands, which needed control from the center of the Empire. Of course, during the antique times, the contact between administrations was not as fast as nowadays, and the questions of local levels could be solved by the local administrations. Such thoughts on the organization of the relationships between different levels of authorities influenced the formation of the principle of subsidiarity.

The principle has its place in the religious doctrine, which is not "legal" by the character, but still includes the features of management between levels of groups and associations in combination with ethical approach at its roots. The principle of subsidiarity is respected together with the principles of solidarity and social justice, which are of fundamental character for the Catholicism. Such approach has also influenced the Ukrainian Greekcatholic church. Volodymyr Moroz, underlines in his research that the general catholic doctrine (and the Ukrainian Greek-catholic doctrine) prescribes that members of political groups should respect the autonomy and independency of human being. In the catholic interpretation of the principle of subsidiarity, it is inconsistent for the society or more powerful group of people to take responsibilities for the actions that could be done by the certain subject itself, providing the lower group the respect to act by themselves on certain matters [1, p. 92-94].

After the mentioning of the history and the usage of the principle of subsidiarity in the system, which is not the legal system, but religious doctrine, based on ethical norms, the attention should be paid to the legal systems and the notion of the principle of subsidiarity as the legal principle.

From the point of view of Paulo Carozza, "subsidiarity is the principle that each social and political group should help smaller or more local ones accomplish their respective ends without, however, arrogating those tasks to itself" [2,p.38]. Such perspectivecanbepresumed as the broad understanding of the principle of subsidiarity as the legal principle, as it may be referred to many different social and political groups, associations, institutions. At this sense, the principle of subsidiarity provides respect to the freedom, discretion of the lower (or other) levels in achieving certain tasks and providing support in cases where needed. The principle of subsidiarity was used by Montesquieu and Locke, who underlined that the principle is important for the functioning of the secular federal State. Such position is logical, as the principle of subsidiarity reveals the administrative or regulatory aspects within it and has features of administrative law principle. The federal States always have the distinction between the federal level, authorities of the federal level, and the local levels with the authorities of the local levels. To verify the functioning, the machinery of work between the federal level and the local institutions, the legislation determines their powers, and to better function, the principle of subsidiarity is used for the support of the lower levels by the centralized (federal) authorities. According to such position, the lower (local) levels are highly motivated to accomplish the tasks that appear in front of them without the interference of the higher authority, who may not be the closest to the problems that should be solved. Therefore, the principle of subsidiarity provides the determination of tasks and powers with freedom to solve some them at lowest possible level.

In addition, providing such respect to the local authorities or any lower authorities, the principle of subsidiarity works positively as the part of the modern constitutional State and of modern democratic society, where the freedom and social justice are respected.

Turning attention to the classifications and the position of the principle of subsidiarity within them, some examples should be named. In the monography of Alla Pukhtetska she underlines that the principle of subsidiarity should be known as a part of the principles of administrative law, when an international or inter-State organization uses it while functioning. In the first classification of principles, Alla Pukhtetska classifies them by the "anchoring source" [3, p. 45], according to which the principle of subsidiarity is flexible. This is because now the principle is referred to in the case law of the European Court of Human Rights. At the same time, by Protocol 15 to the European Convention on Human 
Rights, the principle will be officially added to the Preamble of the Convention and will be in the main legal source of the ECHR protection system, but still will be used in the case law.

The second classification, which Alla Pukhtetska mentions and which includes the principle of subsidiarity is the classification of "the institutional principles". This classification is connected to the constitutional principle of the division of powers and mentions the principles of decentralization, deconcentration and centralizations as the basic principles. According to such classification, the principle of subsidiarity is mentioned in the group of the principles that come from the mentioned basic three principles. From such point of view, the principle of subsidiarity becomes a sub-principle to the basic and takes its roots from them [3, p. 70-71].

The third classification that is mentioned by Alla Pukhtetska is the classification of the German scholar Yurgen Schwarze who included the principle of subsidiarity and the principle of respect to the fundamental human rights to his group of the principles of European administrative law. To the view of the scholar, these principles seriously influenced the integration of the European States because of the common views of the European region on certain standards of human life [4, p. 450-451]. Alla Pukhtetska, in addition to the view of Yurgen Schwarze, mentions that his classification combines not only the European administrative law principles, but also separate principles of administrative law, such as proportionality, that with subsidiarity has also become one of the principles that regulate the relationships of the institutions of the European legal systems [3, p. 46].

After the research on the classifications and groups of the principles within which the principle of subsidiarity is placed, the attention should be paid to the legal systems of the European States where the principle is used as in practice and in the fundamental basis of the relationships between the institutions.

In the dissertation on the public regulation of the European Union and European Community Ihor Hrytsiak, analyses the principles of European administration in perspective of "institutional approach". Ihor Hrytsiak adds the principle of subsidiarity to the principles of decentralization, deconcentration, meaning that the powers should be divided between levels and decentralized from the EU government. To the position of the professor, the principle of subsidiarity is a part of the complex method of policy coordination within the EU system [5, p. 16]. The European Union resembles a supranational regional organization, a union of European States, which needs coordination of responsibilities between the levels of the supranational (EU-government) institutions and the Member States institutions (national level). To provide such regulation, which is a public regulation of supranational level in character, some principles are used and even defined in the "primary EU law", which is a kind of the "constitutional" importance for the European Union.

The principle of subsidiarity is mentioned in Article 5(3) of the Treaty on European Union, which prescribes that in the spheres, which do not fall within the exclusive competence of the Union, it shall act only when the objectives of the proposed action cannot be sufficiently achieved by the Member States by themselves [6, p. 6]. By this Article, the Treaty on European Union, at the supranational level defines that principle of susbsidiarity works in the context of division of powers, separating the competences of the EU institutions and the competences of the national bodies. In cases where national bodies within their competences cannot achieve the positive result or deal with certain task, the EU government can "suplement" the national bodies with resources or by other means, to gain the needed result. In supporting such approach, Ihor Hrytsiak has named the principle of subsidiarity within the system of relationships of EU institutions as the "working tandem", connecting the aim of the EU and the methods used to achieve them in cooperation of national and supranational levels [5, p. 11].

The next object of research is the legal system of the European Convention of Human Rights, which is also a supranational regional system, but of the different goals. Within the European Convention on Human Rights lies the triangle of cooperation between the national authorities of High Contracting Parties to the Convention, the European Court of Human Rights and the Council of Europe, in the middle of which as the legal basis of the protection of human rights lies the Convention. In the human rights protection machinery of the mentioned system, the Strasbourg Court is the supranational institution.

The principle of subsidiarity of this system is actively used, as a definition of cooperation between national and supranational body in implementing of the conventional rights and enforcing the decisions of the Strasbourg Court. The official interpretation of the principle of subsidiarity was done in the Follow-up Note on the principle of subsidiarity of the Jurisconsult of the Court, which happened after the Interlaken Conference in 2010 where the attention to the importance of the principle for the system was paid. 
According to the Follow-up, the principle is used differently by the ECHR and the EU. Within European Union, the principle is called "competitive subsidiarity" and is of competition of powers between the levels of EU institutions and national bodies of Member States, with some supplementing from the higher level, which was mentioned earlier. Within ECHR, it is "complementary subsidiarity" [7, p. 2]. According to the "complementary subsidiarity" of the Strasbourg Court protection system, the main role in protecting human rights is upon the High Contracting Parties on guaranteeing the remedies for the violation, implementing the Convention in their legal systems with discretion on the procedure and the Strasbourg Court can be referred to only when the national authorities have failed in mentioned matters or they need official interpretation of the Convention.

Jurisconsult underlines such types of the principle of subsidiarity as "procedural subsidiarity", which defines the cooperation between the Strasbourg Court and the national authorities [7, p. 6], and "substantive subsidiarity", which defines responsibilities in decisionmaking [7, p. 9].

In addition to the approach to the principle of subsidiarity within the European Convention on Human Rights protection system, Italian judge Sabino Cassese and names it a "judicial subsidiarity", as another type of the principle of subsidiarity. According to his position, this certain type of subsidiarity is closely connected with the "indirect ruling" of the European Convention on Human Rights of the High Contracting Parties. In addition, the principle underlines the power of the decisions of the Strasbourg Court for High Contracting Parties. In this way, it combines the legal character and the judicial character of the principle. Judge Cassese underlines that the principle of subsidiarity is now known to be a common principle of international law, in the scope of it's role in defining of the relationships between different levels or groups. In the Convention system, Sabino Cassese defines that the principle of subsidiarity combines "shared" and "uniform" character for the High Contracting parties when they apply the Convention to their legal systems. In this case, "uniformity is balanced with respect for national identities, through the requirement of the prior exhaustion of national remedies" [8, p. 11]

\section{Conclusions}

In the provided research, it can be seen that the principle of subsidiarity is a principle with: 1) long roots starting from antique times and that has influenced the catholic doctrine seriously from the ethical point; 2) being the principle that regulates and defines the relationships between different levels of groups, associations, institutions, it has got the character of administrative law principle and has a close connection to the public regulations, including regulation of relationships between the national and supranational levels, represented by the European Union and the European Convention on Human Rights legal systems, that are of the same features as regulations within the State, but of different goals and mechanisms; 3 ) the principle of subsidiarity is connected to the principles of decentralization, delegation, that help to provide more freedom for the local or other lower from the centralized authority levels and share powers with them, as it is made in the legal system of the European Union, where the principle is respected; 4 ) taking into account the modern tendencies of the constitutional States, where rights and freedoms of citizens are highly respected, the principle of subsidiarity should get more popularization in modern Europe, and for the States that want to join the European Union, including Ukraine; $5)$ when the principle of subsidiarity will be respected and noticed administrative reform process of Ukraine, and within the legal doctrine, the understanding of the machinery of the European Union will be better understood and the euro integration processes eased.

\section{References:}

1. Мороз. В. Функціональні принципи соціального вчення Української греко-католицької церкви (1991-2011): історико-релігієзнавчий аналіз. Київ : Схід. № 4 (130) липень-серпень, 2014. C. $92-96$.

2. Carozza P.G. Subsidiarity as a Structural Principle of International Human Rights Law. Am. J. Int'l L 97, 2003. 79 p.

3. Пухтецька А.А. Європейські принципи адміністративного права : монографія. Київ : Нац. ун-т ім. Т. Шевченка. Вид-во «ЛОГОС». 2-ге вид., 2014. $236 \mathrm{c}$.

4. Schwarze J. European Administrative Law. Luxembourg: office for of publ of European Communities. The American Journal of Comparative Law. Vol. 42. No. 2, 1994. 452 p.

5. Грицяк I.А. Розвиток європейського управління в контексті впливу на державне управління в Україні : автореферат дисертації. Київ : Нац. Акад. Держ. Упр. При Президентові України, 2006. 30 c.

6. Consolidated Version Of The Treaty On European Union. Official Journal. 2012. 390 p. P. 326.

7. Jurisconsult Interlaken Follow-Up. Principle of Subsidiarity, 2010. $17 \mathrm{p}$.

8. Cassese S. Ruling indirectly judicial subsidiarity in the EctHR : seminar. Strasbourg: Dialogue between judges, 2015. 19 p. 
Стаття присвячена висвітленню питання про роль та значення приниипу субсидіарності як одного із приниипів, який допомагає регулювати взаємозв'язки між різними рівнями влади, установами, асочіачіями. 3 багаторічною історією ией принцип натепер стає актуальним для розвитку сфери державного регулювання різних правових систем демократичних держав та регіональних міжнародних організацій. Приниип субсидіарності є невід'ємною частиною правових систем Європейської конвениії про захист прав людини та основоположних свобод, та правового порядку європейського Союзу. Проте маючи «широке» та «вузьке» значення, підходи до цього приниипу можуть відрізнятися. Крім того, стаття ставить питання про процеси, що вплинули на історичний розвиток приниипу субсидіарності, оскільки він не є виключно правовим принципом і його можна побачити в інших сферах, таких як релігійна доктрина католицької церкви, яка має етичні приниипи у ї базисі. Проте, звертаючи увагу на роль приниипу в сучасних правових системах, також досліджується питання про значення приниипу для фактичного майбутнього України, оскільки приниип може брати участь у базовій групі приниипів, які мають регулювати адміністративні реформи та взаємозв'язки інститутів. Дослідження шукає зв'язок приниипу субсидіарності з іншими принципами адміністративного права та класифікаиією принципів, які можуть допомогти визначити позицію приниипу субсидіарності в системі сучасного адміністративного права. У статті звернено увагу на підхід не лише науковиів до приниипу субсидіарності, але й суддівський з точки зору механізму роботи иього приниипу в рамках правової системи Європейської конвенцї з прав людини та основоположних свобод як приклад використання одного з видів «спеиифічного» сенсу приниипу субсидіарності. Зрештою, у статті підкреслюється важливість обізнаності та поваги до приниипу субсидіарності відповідно до тендениій сучасних демократичних держав та майбутнвого розвитку правових держав, в яких забезпечується повага до прав і свобод іх громадян, у чому приниип субсидіарності допомагає гарантувати реалізацію таких прав і свобод.

Ключові слова: принципи адміністративного права, публічне регулювання, публічна влада, Європейський Союз, Європейська Конвенція із захисту прав людини та основоположних свобод. 